\title{
SH003-induced G1 phase cell cycle arrest induces apoptosis in HeLa cervical cancer cells
}

\author{
KANG MIN LEE ${ }^{1}$, KANGWOOK LEE ${ }^{1 *}$, YOUN KYUNG CHOI ${ }^{2 *}$, \\ YU-JEONG CHOI $^{3 *}$, HYE-SOOK SEO $^{1 *}$ and SEONG-GYU KO ${ }^{4}$ \\ ${ }^{1}$ Department of Science in Korean Medicine, Graduate School, Kyung Hee University, Seoul 02247; \\ ${ }^{2}$ Jeju International Marine Science Center for Research \& Education, Korea Institute of Ocean Science and Technology, \\ Jeju 63349; ${ }^{3}$ Department of Cancer Preventive Material Development, Graduate School, Kyung Hee University; \\ ${ }^{4}$ Department of Preventive Medicine, College of Korean Medicine, Kyung Hee University, Seoul 02247, Republic of Korea
}

Received August 29, 2016; Accepted May 3, 2017

DOI: $10.3892 / \mathrm{mmr} .2017 .7597$

\begin{abstract}
Cervical cancer is a prevalent disease that may lead to mortality in women. In spite of the development of common therapeutic agents to treat cancer, there are several limitations of their use owing to side effects and drug resistance, which may induce cancer recurrence. The anticancer effects of the new herbal mixture SH003 (comprising Astragalus membranaceus, Angelica gigas and Trichosanthes kirilowii Maximowicz) have been examined in various types of cancer. Thus, the present study hypothesized that $\mathrm{SH} 003$ may be an effective treatment for cervical cancer. SH003 treatment inhibited the growth of HeLa cells, whereas it did not affect the growth of rat intestinal epithelial cells. In addition, SH003 treatment increased the expression of apoptosis-related proteins and promoted apoptotic cell death in HeLa cells. SH003 treatment also led to G1 phase arrest in HeLa cells. Furthermore, SH003 treatment induced the production of reactive oxygen species (ROS); however, ROS production did not appear to be related to SH003-mediated apoptosis. Results from the present study indicated that the SH003-induced inhibition of HeLa cell growth may be mediated through G1 phase arrest and extrinsic apoptosis, suggested that $\mathrm{SH} 003$ may be a potential treatment for cervical cancer.
\end{abstract}

\section{Introduction}

Cervical cancer is a disease with poor prognosis among women worldwide (1-3). Surgery assessment of local disease

Correspondence to: Professor Seong-Gyu Ko, Department of Preventive Medicine, College of Korean Medicine, Kyung Hee University, 26 Kyungheedaero, Hoegi, Seoul 02247, Republic of Korea E-mail: epiko@khu.ac.kr

*Contributed equally

Key words: SH003, herbal medicine, cervical cancer, apoptosis, cell cycle state, including tumor size assessment and vaginal and parametrial involvement, is good during early stages of the disease; however, the evaluation of tumor size and vaginal and parametrial involvement are difficult in advanced- and late-stages, such as in those patients who do not qualify for up-front surgery $(4,5)$. Owing to such limitations, alternative approaches and more efficient remedies are necessary to treat cervical cancer other than surgical operation, chemotherapy and vaccination.

Previous studies have reported on the use of traditional herbal medicines as alternative cancer therapies (6-8), including a number of studies on HeLa cervical cancer cells that used herbal medicines as therapeutic agents and compounds for potentially treating cervical cancer (9-11). Our previous study developed a new herbal medicine, called SH003, which is composed of Astragalus membranaceus (Am), Angelica gigas (Ag) and Trichosanthes kirilowii Maximowicz (Tk), based on the principles of traditional Chinese medicine $(12,13)$. Am and Ag have been reported to be effective treatments for a number of diseases, including hematologic diseases, endocrine disorders and cancers (14-19). Therapeutic effects of Tk have also been indicated for various cancer types, such as leukemia, hepatocellular carcinoma, colon cancer, non-small cell lung cancer and gastric cancer (18,20-25). Several previous studies have demonstrated that a mixture of those components named SH003 was better therapeutic effect than each component in other types of cancer $(12,13,17,26-30)$. Thus, SH003 is likely to be used for cancer treatment as novel herbal mixture.

Apoptosis, or programmed cell death, is characterized by cell shrinkage, membrane blebbing, maintenance of organelle integrity, and DNA condensation and fragmentation (31). There are two subtypes of the apoptotic pathway: The extrinsic, or receptor-mediated, pathway and the intrinsic, or mitochondria-mediated, pathway (32). The extrinsic apoptotic pathway involves the so-called 'death receptors', such as Fas receptor, tumor necrosis factor receptor and death receptor, and their associated extracellular ligands (33-35). These apoptotic factors lead to the activation of caspase (casp)-3 and casp8 $(35,36)$. Conversely, the intrinsic apoptotic pathway is activated by a number of different factors, such as genomic and metabolic stresses, and the presence of unfolded proteins, 
which may cause permeabilization of the outer mitochondrial membrane and the release apoptotic proteins into the cytosol (34). Concurrently, cell cycle checkpoints are triggered and apoptosis is induced in cells exhibiting abnormal cell cycle. In particular, the $G_{1}$ phase is regulated by cyclin $D$ proteins (including cyclin $\mathrm{D}_{1}, \mathrm{D}_{2}$ and $\mathrm{D}_{3}$ ), cyclin $\mathrm{E}$ proteins which associate with cyclin-dependent kinase (CDK) 2 to regulate thr progression from $\mathrm{G}_{1}$ into $\mathrm{S}$ phase, $\mathrm{CDK} 2$, $\mathrm{CDK} 4$ and CDK6 (37). The CDKs are a family of serine/threonine protein kinases that are activated at the $\mathrm{G}_{1}$ checkpoint; Cyclin D proteins interact with CDK4/CDK6, and these complexes directly regulate the $\mathrm{G}_{1}$ phase of cell cycle.

The present study investigated the anticancer effects of SH003 in the HeLa cervical cancer cell line. The results demonstrated that SH003 treatment reduced the viability of HeLa cells without affecting that of normal cells. Rat intestinal epithelial cells were used as the control group in the present study, as previously described (38). SH003 treatment led to extrinsic apoptosis and induced the cleavage of casp3, casp8 and poly(ADP-ribose) polymerase 1. SH003 treatment also increased the production of reactive oxygen species (ROS) and induced G1 cell cycle arrest in HeLa cells. Results from the present study suggested that $\mathrm{SH} 003$ may be a potential treatment for cervical cancer.

\section{Materials and methods}

SH0O3 preparation. The production of $\mathrm{SH} 003$ and its components, Am, Ag and Tk, was commissioned to Hanpoong Pharm and Foods Company (Jeonju, Korea), and the extraction procedures were performed as previously reported (12). Briefly, extracts ( $\sim 333 \mathrm{~g}$ each) of Am, Ag and Tk in $10130 \%$ ethanol were obtained by boiling for $3 \mathrm{~h}$ at temperature ranging between 80 and $100^{\circ} \mathrm{C}$. The ethanol extract was filtered, concentrated using vacuum evaporation and freeze-dried at $<60^{\circ} \mathrm{C}$ (average yield $=35.5 \%$ ). Dried extract was then dissolved in $30 \%$ ethanol to prepare a stock solution of $100 \mathrm{mg} / \mathrm{ml}$. The stock solution was stored at $-80^{\circ} \mathrm{C}$ until used.

Cell culture. HeLa human cervical cancer cells (Korean Cell Line Bank, Seoul, Korea) and rat intestinal epithelium (RIE; provided by Dr Joon Woo Lee; Seoul National University, Seoul, Korea) were cultured in Dulbecco's Modified Eagle's Medium (DMEM; Welgene, Gyeongsan, Korea) containing $10 \%$ fetal bovine serum (Welgene) and $1 \%$ penicillin. Cells were maintained at $37^{\circ} \mathrm{C}$ in a $5 \% \mathrm{CO}_{2}$ atmosphere.

Reagents. Methyl thiazolyl tetrazolium (MTT), 2',7'-dichlorofluorescin diacetate (DCFH-DA), N-acetyl L-cysteine (NAC) and 7-aminoactinomycin D (7-AAD) were purchased from Sigma-Aldrich (Merck KGaA, Darmstadt, Germany). Acrylamide/bis-acrylamide solution $(30 \%)$ was purchased from Bio-Rad Laboratories, Inc. (Hercules, CA, USA). Annexin V-fluorescein isothiocyanate (FITC) was purchased from BD Biosciences (San Jose, CA, USA), and 5,5',6,6'-tetrachloro-1,1',3,3'tetraethylbenzimidazolylcarbocyanine (JC-1) was purchased from Biotium Inc. (Freemont, CA, USA).

Western blotting. Radioimmunoprecipitation assay lysis buffer containing protease inhibitors (Dithiothreitol $3 \mathrm{mg} / \mathrm{ml}$,
Phenylmethylsulfonyl fluoride $3 \mu \mathrm{g} / \mathrm{ml}, \mathrm{Na}_{3} \mathrm{VO}_{4} 5 \mu \mathrm{g} / \mathrm{ml}$, NaF $5 \mu \mathrm{g} / \mathrm{ml}$ and protease inhibitor $4 \mu \mathrm{g} / \mathrm{ml}$ ) was used for cell lysis for $20 \mathrm{~min}$ at $4^{\circ} \mathrm{C}$, and supernatants were collected by centrifugation at $16,600 \mathrm{xg}$ for $20 \mathrm{~min}$ at $4^{\circ} \mathrm{C}$. Protein concentration was measured using a Bradford assay kit (Bio-Rad Laboratories, Inc.). Proteins $(15 \mu \mathrm{g})$ were separated by $8-12 \%$ SDS-PAGE and transferred to nitrocellulose membranes. Membranes were blocked at room temperature for $1 \mathrm{~h}$ in $2 \%$ skim milk containing 3\% bovine serum albumin (Sigma-Aldrich; Merck $\mathrm{KGaA}$ ) and probed with the primary antibodies raised against the following proteins at $4^{\circ} \mathrm{C}$ overnight: Cleaved (C)-casp3 (cat no. 9661; 1:2,000), C-casp8 (cat no. 9661; 1:2,000), casp9 (cat no. 9502; 1:50,000), poly(ADP-ribose) polymerase 1 (PARP1; cat no. 9542; 1:50,000), phosphorylated (p)-p53 (cat no. 9284; 1:50,000), cyclin-dependent kinase (CDK) 4 (cat no. 12790s; 1:50,000) and CDK6 (cat no. 3136; 1:50,000), all from Cell Signaling Technology, Inc. (Danvers, MA, USA); $\beta$-actin (cat no. sc47778; 1:50,000), Bcl-2 (cat no. sc7382; 1:10,000), Bcl-2-like protein (Bax; cat no. sc-7480; 1:100,000), CDK2 (cat no. sc163; 1:100,000) and cyclin E (cat no. sc-247; 1:5,000) all from Santa Cruz Biotechnology, Inc. (Dallas, TX, USA); cyclin D1 (cat no. 556470; 1:50,000) and retinoblastoma-associated protein (pRb; cat no. 554140; 1:50,000; from BD Biosciences. Membranes were then incubated in room temperature for $1 \mathrm{~h}$ with the following horseradish peroxidase-conjugated secondary antibodies $(1: 1,000)$ : Anti-rabbit immunoglobulin (Ig) G (cat no. 7074) and anti-mouse IgG (cat no. 7076) from Cell Signaling Technology, Inc. Protein bands were visualized using enhanced chemiluminescence (cat no. DG-W250; DoGEN, Seoul, Korea). Blots were semi-quantified by densitometry using ImageJ software version 1.4.3.67 (National Institutes of Health, Bethesda, MD, USA) and normalized to $\beta$-actin.

Cell viability assays. HeLa $\left(5 \times 10^{3}\right)$ and RIE $\left(4 \times 10^{3}\right)$ cells were seeded in DMEM in 96-well plates and treated with various concentrations $(0,100,200$ or $400 \mu \mathrm{g} / \mathrm{ml})$ of either SH003 or one of the individual components (Am, $\mathrm{Ag}$ or Tk) for $72 \mathrm{~h}$ at $37^{\circ} \mathrm{C}$. Subsequently, the medium was discarded and $10 \mu \mathrm{l}$ MTT solution (Sigma-Aldrich; Merck KGaA) in $90 \mu \mathrm{l}$ medium was added to each well. Cells were incubated for $2 \mathrm{~h}$ at $37^{\circ} \mathrm{C}$, and then $100 \mu \mathrm{l}$ dimethyl sulfoxide (DMSO) was added to dissolve the formazan crystals. The absorbance of each sample was measured at $570 \mathrm{~nm}$ using an ELISA microplate reader (Molecular Devices, LLC, Sunnyvale, CA, USA).

Mitochondrial membrane potential assay. HeLa cells $\left(3 \times 10^{5}\right)$ were seeded on $60 \mathrm{~mm}$ dishes and treated with 100, 200 or $400 \mu \mathrm{g} / \mathrm{ml} \mathrm{SH003}$ for $24 \mathrm{~h}$. Control cells received no treatment. Briefly, 100X JC-1 solution was diluted in to $1 \mathrm{X}$ in DMSO. Cells were stained with $4 \mu \mathrm{g} / \mathrm{ml} \mathrm{JC}-1$ solution for $15 \mathrm{~min}$ at $37^{\circ} \mathrm{C}$. In healthy cells, JC-1 accumulates as J-aggregates (FL-2) in the mitochondria and stains them red, whereas in apoptotic cells, the mitochondrial membrane potential collapses and JC-1 remains in the cytoplasm as a monomer (FL-1), emitting green fluorescence. Cells were analyzed using a FACSCalibur Flow Cytometry System (BD Biosciences). Histograms and dot plots were analyzed with CellQuestPro software version 5.2 (BD Biosciences). The M1 gate was calculated based on the control values (no treatment). 
ROS generation assay. ROS generation was detected using the dye DCFH-DA. Briefly, HeLa cells $\left(3 \times 10^{5}\right)$ were plated on $60-\mathrm{mm}$ plates and incubated in DMEM at $37^{\circ} \mathrm{C}$ overnight. Cells were treated with various concentrations of SH003 $(0,100,200$ and $400 \mu \mathrm{g} / \mathrm{ml})$, with or without NAC (2 mM). Subsequently, $1 \mu \mathrm{l} / \mathrm{ml}$ DCFH-DA was added and cells were incubated for $1 \mathrm{~h}$ at $37^{\circ} \mathrm{C}$ and samples were analyzed using the FACSCalibur Flow Cytometry System (BD Biosciences). Histograms and dot plots were analyzed using CellQuestPro Software version 5.2 (BD Biosciences). NAC (2 mM) was used for inhibition of ROS generation.

Annexin V-FITC/7-AAD apoptosis assay. Rates of apoptosis were measured by annexin V-FITC/7-AAD assay. HeLa cells $\left(3 \times 10^{5}\right)$ were treated with $400 \mu \mathrm{g} / \mathrm{ml} \mathrm{SH} 003$ for $48 \mathrm{~h}$ and $2 \mathrm{mM}$ $\mathrm{NAC}$ for $2 \mathrm{~h}$ at $37^{\circ} \mathrm{C}$, and then stained with $1.25 \mu \mathrm{l}$ annexin V-FITC in $1 \mathrm{X}$ binding buffer and $1 \mu 1$ 7-AAD for $15 \mathrm{~min}$ at room temperature in the dark. Apoptotic cell population was analyzed by FACSCalibur Flow Cytometry System, measuring the signal by FL-1 (green, $525 \mathrm{~nm}$ ) and FL-3 (red, 620-767 nm). Cells were analyzed using a FACSCalibur Flow Cytometry System(BD Biosciences). Histograms and dot plots were analyzed with CellQuestPro software version 5.2 (BD Biosciences). The M1 gate was calculated based on the control values (no treatment).

Cell cycle assay. HeLa cells were plated in DMEM in 60-mm dishes at a density of $7 \times 10^{5}$ cells/dish and treated with various concentrations of SH003 $(0,100,200$ and $400 \mu \mathrm{g} / \mathrm{ml})$ for $24 \mathrm{~h}$ at $37^{\circ} \mathrm{C}$. Subsequently, cells were harvested, centrifuged at $221 \mathrm{x} \mathrm{g}$ for $10 \mathrm{~min}$ at $4^{\circ} \mathrm{C}$, fixed with $95 \%$ ethanol at $4^{\circ} \mathrm{C}$ overnight, and washed twice in PBS. Subsequently, cells were stained with $50 \mu \mathrm{l}$ Muse Cell Cycle Assay kit (Merck KGaA) in the dark at room temperature for $30 \mathrm{~min}$. Cell cycle plots were analyzed using the Muse Cell Analyzer (Merck KGaA).

Statistical analysis. Statistical analysis was performed using SPSS software version 22.0 (IBM Corp., Armonk, NY, USA). Data are presented as the mean \pm standard deviation of 3 independent experiments. The statistical significance of the differences between groups was assessed using one-way analysis of variance followed by a post hoc Tukey test for multiple comparisons. $\mathrm{P}<0.05$ was considered to indicate a statistically significant difference.

\section{Results}

Effects of SHOO3 and its components on RIE and HeLa cell viability. An MTT assay was performed to evaluate the cytotoxic effects of Am, Ag, Tk and SH003 on normal RIE cells and HeLa cervical cancer cells. RIE cells were treated with varying concentrations $(100,200$ and $400 \mu \mathrm{g} / \mathrm{ml})$ of each extract or SH003 (Fig. 1A). While SH003 and Am treatment exhibited lower toxicity on RIE cells compared with Ag and Tk, SH003 appeared to be more effective at inducing cell death in HeLa cells compared with Am (Fig. 1A). Conversely, SH003 treatment reduced HeLa cell viability at all concentrations (Fig. 1B), which suggested that SH003 may induce toxicity in cervical cancer cells without affecting normal cell viability.

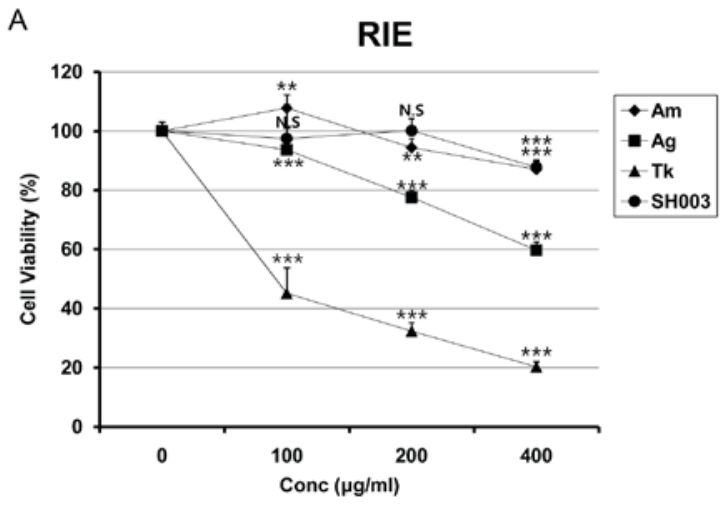

B

HeLa

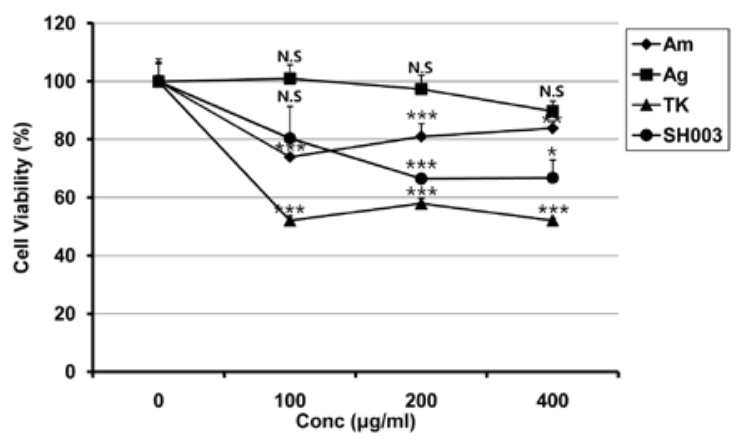

Figure 1. SH003 treatment reduces viability of HeLa cells. (A) RIE and (B) and HeLa cells were seeded in 96-well plates. Following 24-h incubation, cells were treated with various concentrations $(0,100,200$ and $400 \mu \mathrm{g} / \mathrm{ml})$ of Am, Ag, Tk or SH003 for $72 \mathrm{~h}$, followed by MTT assay analysis. Cells were treated with MTT solution for $2 \mathrm{~h}$, followed by $100 \mu \mathrm{l}$ of DMSO. Cell viability was analyzed by an ELISA microplate reader. Experiments were performed in triplicate, and results are presented as the mean \pm standard deviation. ${ }^{*} \mathrm{P}<0.05,{ }^{* *} \mathrm{P}<0.01$ and ${ }^{* * *} \mathrm{P}<0.001$ vs. control $(0 \mu \mathrm{g} / \mathrm{ml})$. Ag, Angelica gigas; Am, Astragalus membranaceus; Conc., concentration; MTT, methyl thiazolyl tetrazolium; RIE, rat intestinal epithelium; Tk, Trichosanthes kirilowii Maximowicz.

SHOO3 induces apoptosis in HeLa cells. SH003-induced apoptosis was examined in HeLa cells. Cells were stained with annexin V-FITC and 7-AAD and analyzed by flow cytometry. SH003 treatments at 200 and $400 \mu \mathrm{g} / \mathrm{ml}$ were revealed to significantly increase the percentage of cells in the early and late apoptosis regions (Fig. 2A). In accordance with these data, SH003 treatment appeared to increase the protein expression levels of C-casp3, C-casp8 and PARP1, but not C-casp9 (Fig. 2B), which indicated that SH003 treatment may induce extrinsic apoptotic cell death in HeLa cells. However, these results were not statistically significant.

SHOO3 does not affect the intrinsic mitochondria-mediated apoptosis pathway in HeLa cells. As $\mathrm{SH} 003$ treatment did not appear to affect the expression level of C-casp9 (Fig. 2B), the effects of $\mathrm{SHOO3}$ on the intrinsic mitochondria-mediated apoptosis pathway were examined by measurement of the $\mathrm{Bax} / \mathrm{Bcl}-2$ ratio, which is important in the intrinsic apoptosis pathway. No significant differences in Bax/Bcl-2 ratios were indicted for HeLa cells exposed to $\mathrm{SH} 003$, which suggested that SH003 may not induce intrinsic apoptosis (Fig. 3A). In addition, changes in mitochondrial transmembrane potential within the cells were analyzed by staining HeLa cells 

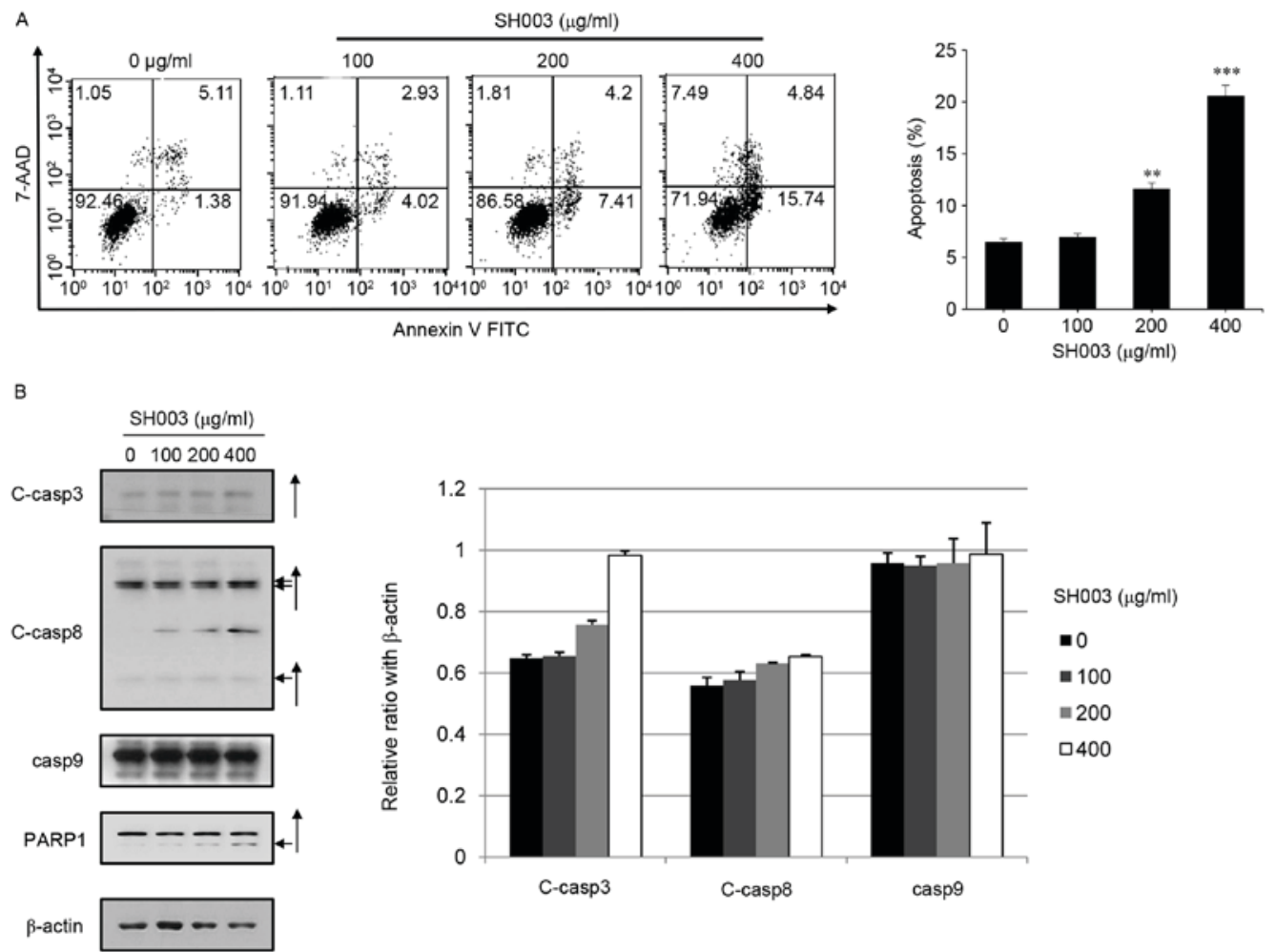

Figure 2. SH003 treatment induces apoptosis in HeLa cells. (A) HeLa cells ( $1 \times 10^{5}$ cells/dish) were seeded on $60 \mathrm{~mm}$ dishes and treated with 0 , 100, 200 or $400 \mu \mathrm{g} / \mathrm{ml} \mathrm{SH003}$ for $48 \mathrm{~h}$. Cells were harvested and stained with 7-AAD and annexin V-FITC in 1X binding buffer. Apoptotic cell death was analyzed by FACSCalibur flow cytometer FL-1 and FL-3 channels. Experiments were performed in triplicate, and results are presented as the mean \pm standard deviation; ${ }^{* *} \mathrm{P}<0.01$ and ${ }^{* * * *} \mathrm{P}<0.001$ vs. control $(0 \mu \mathrm{g} / \mathrm{ml})$. (B) Total cell lysates were prepared and the equal amounts of protein (15 $\left.\mu \mathrm{g}\right)$ were separated by SDS-PAGE, and the membranes were probed with C-casp3, C-casp8, C-casp9 and PARP1 antibodies. $\beta$-Actin was used as a loading control. Arrows indicate the cleaved forms of the proteins. 7-AAD, 7-aminoactinomycin D; C-casp, cleaved caspase; FITC, fluorescein isothiocyanate; PARP1, poly(ADP-ribose) polymerase 1.
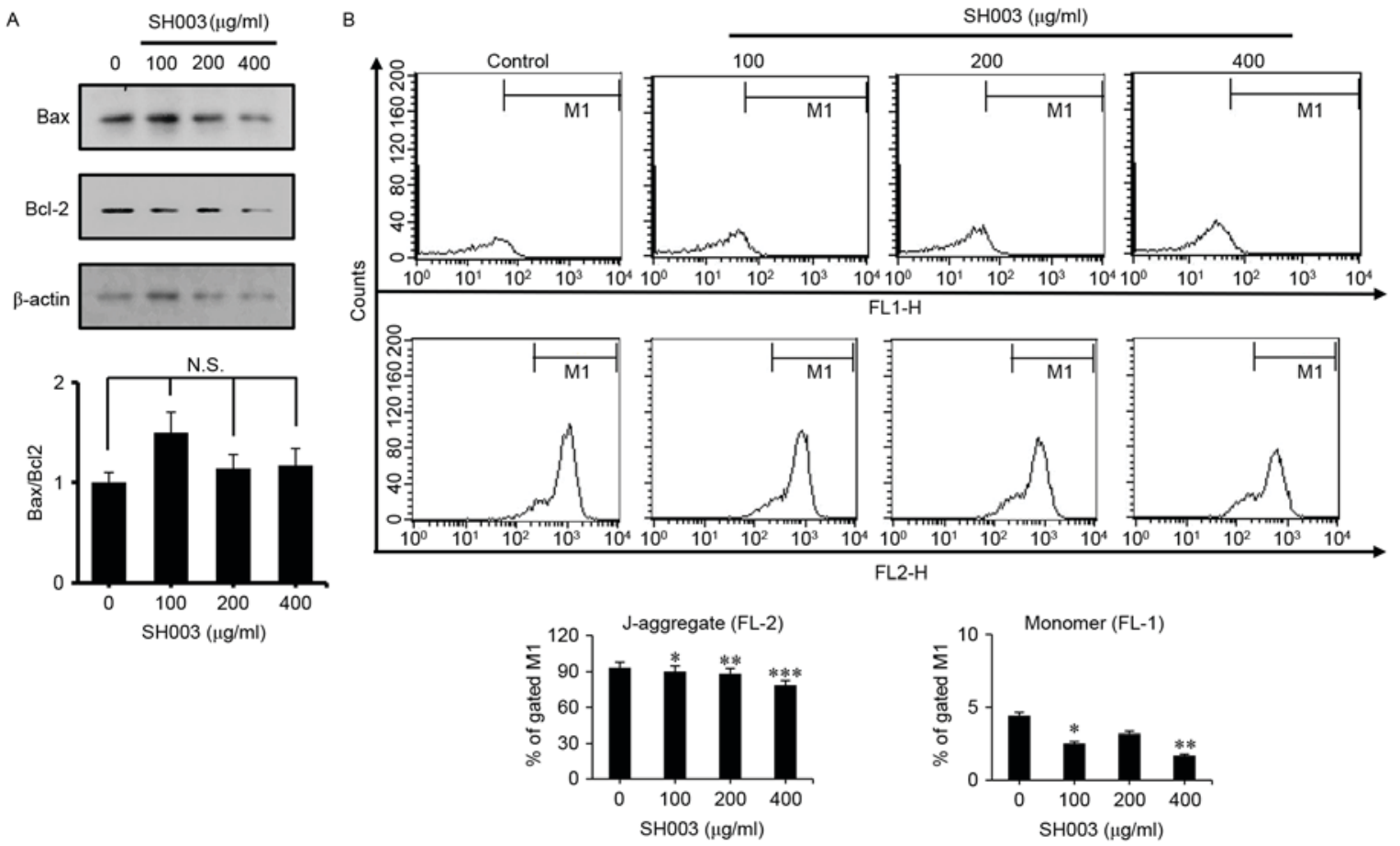

Figure 3. SH003 treatment does not affect intrinsic mitochondria-mediated apoptosis. HeLa cells were treated with 100, $200 \mathrm{and} 400 \mu \mathrm{g} / \mathrm{ml}$ of SH003 for $24 \mathrm{~h}$ prior to testing. (A) Western blotting was performed by using anti-Bax and anti-Bcl-2 antibodies; $\beta$-actin was used as a loading control. Bax/Bcl-2 ratio was calculated by ImageJ software, following densitometric analysis. (B) Following SH003 treatment, cells were harvested and stained with JC-1, and mitochondrial membrane potentials were detected by FACSCalibur flow cytometry using FL-1 and FL-2 channels to detect JC-1 monomers and J-aggregates, respectively. Experiments were performed three times, and results are presented as the mean \pm standard deviation; ${ }^{*} \mathrm{P}<0.05,{ }^{* * *} \mathrm{P}<0.01$ and ${ }^{* * * *} \mathrm{P}<0.001$ vs. untreated control. Bcl, B-cell lymphoma; Bax, Bcl-2-like protein; JC-1, 5,5',6,6'-tetrachloro-1,1',3,3'tetraethylbenzimidazolylcarbocyanine; N.S., not significant. 

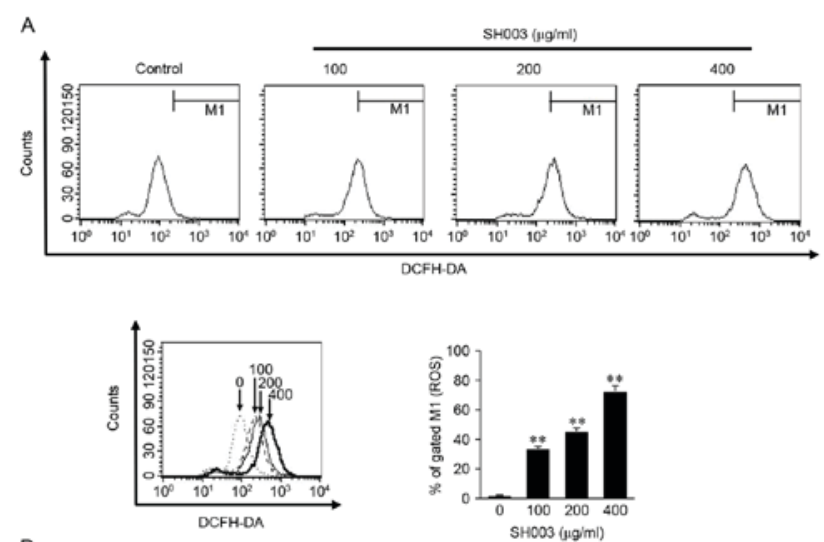

B
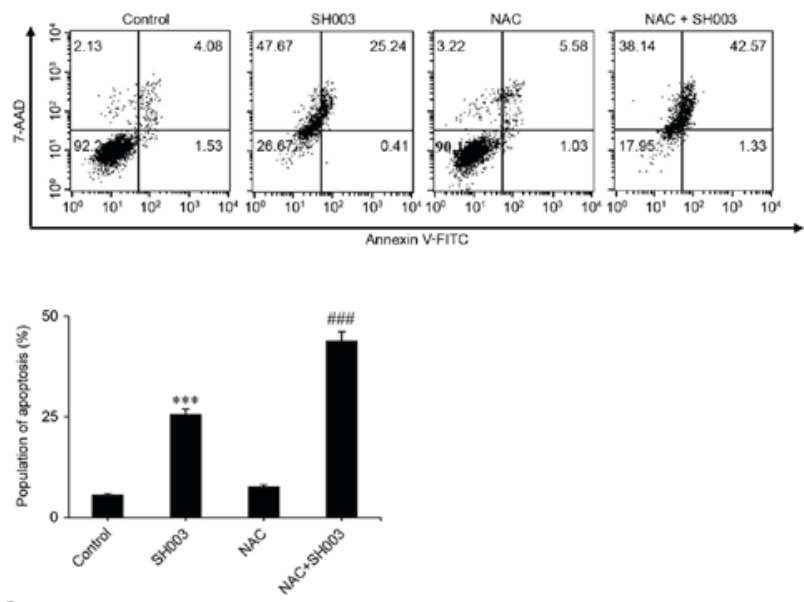

C

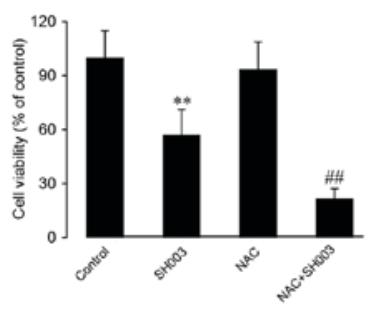

Figure 4. SH003 treatment increases ROS generation in HeLa cells. (A) HeLa cells were treated with various concentrations $(0,100,200$ and $400 \mu \mathrm{g} / \mathrm{ml})$ of SH003 and incubated with DCFH-DA for $1 \mathrm{~h}$. ROS generation of HeLa cells was measured by FACSCalibur flow cytometry. ${ }^{* *} \mathrm{P}<0.01$ vs. untreated control. (B) Cells were pretreated with $2 \mathrm{mM}$ NAC for $30 \mathrm{~min}$, followed by treatment with concentrations of SH003 for $48 \mathrm{~h}$. Cells were stained with DCFH-DA for $1 \mathrm{~h}$, then stained with 7-AAD and annexin V-FITC in 1X binding buffer Apoptotic cell death was analyzed by FACSCalibur flow cytometer. ${ }^{* * *} \mathrm{P}<0.001$ vs. untreated control; ${ }^{\# \# P}<0.001$ vs. SH003 treatment only. (C) HeLa cells were pretreated with $2 \mathrm{mM}$ NAC for $30 \mathrm{~min}$, followed by treatment with SH003 for $48 \mathrm{~h}$. MTT solution was added to the cells and incubated for $2 \mathrm{~h}$, followed by the addition of $100 \mu 1$ of DMSO to each well. Cell viability was analyzed by ELISA microplate reader. ${ }^{* *} \mathrm{P}<0.01$ vs. untreated control; ${ }^{\# \#} \mathrm{P}<0.01$ vs. SH003 treatment only. All data are presented as the mean \pm and standard deviation of 3 independent experiments. DCFH-DA, 2',7'-dichlorofluorescin diacetate; FITC, fluorescein isothiocyanate; MTT, methyl thiazolyl tetrazolium; NAC, N-acetyl L-cysteine; ROS, reactive oxygen species.

with JC-1 and measuring the monomeric form (via channel FL-1) and J-aggregates (via FL-2). SH003 did not induce a low mitochondrial transmembrane potential, suggesting that SH003 does may not induce apoptosis through the mitochondria-mediated pathway (Fig. 3B), but through the extrinsic pathway.
SHOO3 increases ROS generation in HeLa cells. Elevated ROS levels have previously been implicated in apoptosis (39-41). To investigate whether SH003 treatment influenced ROS generation, HeLa cells were stained with DCFH-DA and analyzed by flow cytometry. The varying concentrations of SH003 treatment significantly increased ROS generation in a dose-dependent manner (Fig. 4A). However, SH003-induced apoptosis was not related with an increase in ROS levels, as co-treatment with $\mathrm{SH} 003$ and NAC resulted in increased apoptosis (Fig. 4B) and reduced cell viability compared with SH003 alone (Fig. 4C). These results indicated that apoptosis induced by SH003 is not dependent on the ROS-mediated pathway.

SHOO3 induces $G_{1}$ cell cycle arrest in HeLa cells. Chemotherapy commonly inhibits cancer growth by inducing cell cycle arrests (42-44) and the present findings indicated that SH003 may have potential to induce cell cycle arrest in cancer cells. Western blot analysis was conducted to investigate whether SH003 induced cell cycle arrest in HeLa cells. SH003 treatment was demonstrated to decrease the protein expression levels of CDK2, CDK4, CDK6 and cyclin D. In addition, SH003 treatment decreased p-p53 and pRb levels (Fig. 5A). In addition, cell cycle analysis was performed with a Muse Cell Analyzer. The number of cells at the $\mathrm{G}_{1}$ phase increased in HeLa cultures treated with varying concentrations of SH003 (Fig. 5B). These results indicated that $\mathrm{SH} 003$ may reduce $\mathrm{G}_{1}$ phase cell cycle associated protein expression and arrests the cell cycle at the $\mathrm{G}_{1}$ phase.

\section{Discussion}

As therapeutic agents without toxic side effects, traditional herbal medicines have been the focus of several studies on cancer $(45,46)$. One such traditional herbal medicine, SH003, has been reported previously as a potential novel anticancer agent for breast and prostate cancer (12). In the present study, SH003 treatment was demonstrated to induce extrinsic apoptosis in HeLa cervical cancer cells.

Conventional chemotherapeutic agents for cancer treatment commonly induce apoptotic death (9-11), and traditional herbal medicines have exhibited anticancer effects against cervical cancer cells by promoting apoptosis (9-11). Previous studies have demonstrated that $\mathrm{SH} 003$ treatment suppressed the growth of breast and prostate cancer cells by inducing apoptosis $(12,47,48)$. It has been also reported that SH003 co-treatment with doxorubicin may have synergistic effects on the promotion of apoptotic death in MDA-MB-231 human breast cancer cells (49). Consistent with these previous results, the present study demonstrated that SH003-induced growth inhibition of HeLa cells may be mediated by the induction of apoptosis.

SH003 comprises Am, Ag and Tk, which have previously been indicated as effective treatments for a variety of diseases, such as hematologic diseases, endocrine disorders, leukemia, hepatocellular carcinoma, colon cancer, non-small cell lung cancer and gastric cancer (14-25). Although the mechanism of action remains unclear, the mixture of $\mathrm{Ag}$, Am and Tk may complement the individual properties of each component. Previous studies have demonstrated that 
A
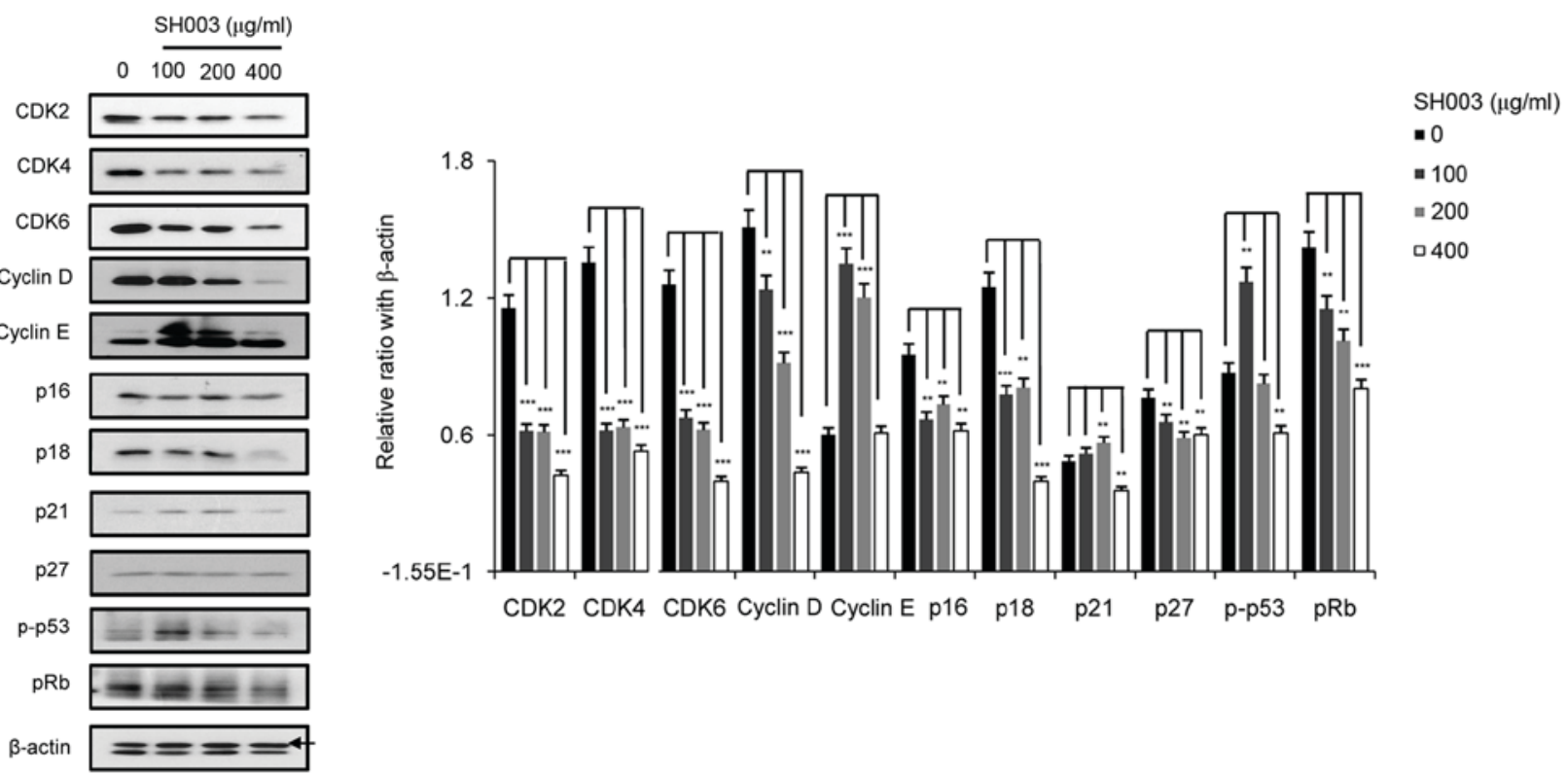

B
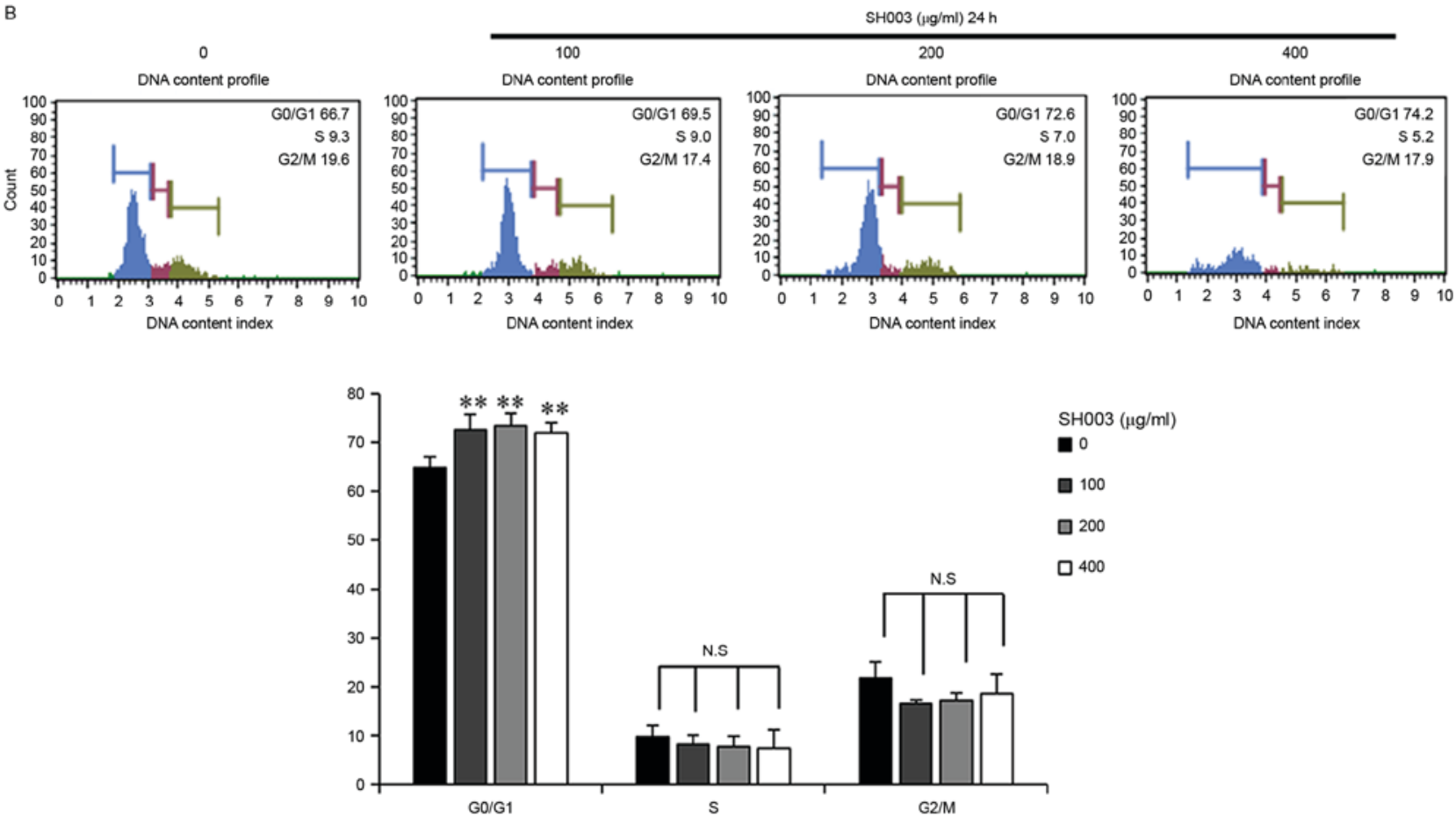

Figure 5. SH003 induces $\mathrm{G}_{1}$ cell cycle arrest in HeLa cells. (A) Cells were treated with varying concentrations (0, 100, $\left.200 \mathrm{and} 400 \mu \mathrm{g} / \mathrm{ml}\right)$ of SH003 for $24 \mathrm{~h}$, harvested and used for western blot analysis. Each sample was separated by SDS-PAGE, and then transferred to a membrane. The membrane was probed with antibodies against CDK2, CDK4, CDK6, cyclin D, cyclin E, p-p53 and pRb. $\beta$-Actin (upper band) was used as a loading control. Cell cycle associated protein levels were calculated by densitometric analysis using ImageJ software. (B) Cells were plated 7x10 and treated with varying concentrations of SH003 for $24 \mathrm{~h}$. Cells were harvested, fixed in 95\% ethanol and stained with $50 \mu \mathrm{l}$ of Muse Cell Cycle Assay reagent; cell cycle profiles were analyzed using Muse Cell Analyzer. Experiments were performed in triplicate, and results are presented as the mean \pm standard deviation. ${ }^{* *} \mathrm{P}<0.01$ and ${ }^{* * *} \mathrm{P}<0.001$ vs. untreated control. CDK, cyclin dependent kinase; N.S., not significant; p, phosphorylated; pRB, retinoblastoma-associated protein.

SH003 may be more effective to inhibit the growth of breast cancer cells compared with the effects of the separate components $(12,48,49)$. Consistent with these previous results, the present data indicated that $\mathrm{SH} 003$ treatment exhibited better effects on the inhibition of HeLa cancer cell growth than its constituents' effect. In addition, SH003 appeared to be less toxic to normal RIE cells compared with cells treated with Am, Ag or Tk alone, which suggested that SH003 may be a possible treatment for cervical cancer without serious adverse effects. However, further studies, investigating the effects of SH003 and its components on apoptosis, ROS levels and cell cycle arrest on normal cervical cells, are required in order to establish the safety profile of SH003.

Cell cycle entry is critical for homeostatic control in the cell (31); however, when cells suffer from cellular damage, cell cycle arrest is induced by various mechanisms such as the inhibition of cyclin and CDK expression. These regulations are commonly referred to as cell cycle checkpoint (50). 
In the present study, $\mathrm{SH} 003$ treatment reduced the levels of expression for $\mathrm{G}_{1}$ phase associated CDKs (CDK2, CDK4 and CDK6) and cyclin D. Although the present data indicated that inhibition of cell growth by SH003 is mediated through cell cycle arrest at $G_{1}$ phase, further study should be performed to determine the mechanisms of CDK inhibition.

Increased ROS production has been associated with promoting apoptosis $(40,51,52)$. In the present study, SH003 treatment increased ROS production in a dose-dependent manner, whereas treatment with NAC did not block ROS generation (data not shown) and apoptosis in SH003-treated HeLa cells. The present data indicated that SH003-mediated apoptosis was not correlated with increased ROS production.

In conclusion, the present study is the first to suggest, to the best of our knowledge, that $\mathrm{SH} 003$ induces extrinsic apoptosis in HeLa cells. Although a mechanism of SH003 action on treating cervical cancer cells is required to clarify which of the active compounds of $\mathrm{SHOO3} \mathrm{show} \mathrm{anticancer} \mathrm{effects} \mathrm{against}$ cervical cancer cells, the present study suggests that SH0O3 may be effective for the treatment of cervical cancer.

\section{Acknowledgements}

This study was supported by The Korean Medicine R\&D Project of the Ministry of Health and Welfare (grant no. B110043).

\section{References}

1. Popat K, McQueen K and Feeley TW: The global burden of cancer. Best Pract Res Clin Anaesthesiol 27: 399-408, 2013.

2. Siegel RL, Miller KD and Jemal A: Cancer statistics, 2015. CA Cancer J Clin 65: 5-29, 2015

3. Vaccarella S, Bruni L and Seoud M: Burden of human papillomavirus infections and related diseases in the extended Middle East and North Africa region. Vaccine 31 (Suppl 6): G32-G44, 2013.

4. Pecorelli S, Zigliani L and Odicino F: Revised FIGO staging for carcinoma of the cervix. Int J Gynaecol Obstet 105: 107-108, 2009

5. Dueñas-González A, Cetina L, Coronel J and González-Fierro A The safety of drug treatments for cervical cancer. Expert Opin Drug Saf 15: 169-180, 2016.

6. Choi EJ and Kim GH: Antioxidant and anticancer activity of Artemisia princeps var. Orientalis extract in HepG2 and Hep3B hepatocellular carcinoma cells. Chin J Cancer Res 25: 536-543, 2013.

7. Fang L, Wang Z, Kong WY, Feng JG, Ma SL and Lin NM: Anti-tumor and apoptotic effects in vitro and in vivo of a traditional Chinese medicine prescription. Chin Med J (Engl) 124: 3583-3587, 2011.

8. Cheng YL, Chang WL, Lee SC, Liu YG, Chen CJ,Lin SZ, Tsai NM, Yu DS, Yen CY and Harn HJ: Acetone extract of Angelica sinensis inhibits proliferation of human cancer cells via inducing cell cycle arrest and apoptosis. Life Sci 75: 1579-1594, 2004.

9. Sato T, Kita K, Sato C and Kaneda A: Hochu-ekki-to (Bu-zhong-yi-qi-tang), a herbal medicine, enhances cisplatin-induced apoptosis in HeLa cells. Mol Med Rep 12: 6215-6220, 2015.

10. Duan D, Zhang J, Yao J, Liu Y and Fang J: Targeting thioredoxin reductase by parthenolide contributes to inducing apoptosis of HeLa cells. J Biol Chem 291: 10021-10031, 2016.

11. Qian S and Li M: Chamaejasmine induces apoptosis in HeLa cells through the PI3K/Akt signaling pathway. Anticancer Drugs 28: 40-50, 2017.

12. Choi YK, Cho SG, Woo SM, Yun YJ, Park S, Shin YC and Ko SG: Herbal extract SH003 suppresses tumor growth and metastasis of MDA-MB-231 breast cancer cells by inhibiting STAT3-IL-6 signaling. Mediators Inflamm 2014: 492173, 2014.

13. Choi HS, Kim MK, Lee K, Lee KM, Choi YK, Shin YC, Cho SG and Ko SG: SH003 represses tumor angiogenesis by blocking VEGF binding to VEGFR2. Oncotarget 7: 32969-32979, 2016.
14. Zhang J, Li L, Jiang C, Xing C, Kim SH and Lü J: Anti-cancer and other bioactivities of Korean Angelica gigas Nakai (AGN) and its major pyranocoumarin compounds. Anticancer Agents Med Chem 12: 1239-1254, 2012.

15. Yang B, Xiao B and Sun T: Antitumor and immunomodulatory activity of Astragalus membranaceus polysaccharides in $\mathrm{H} 22$ tumor-bearing mice. Int J Biol Macromol 62: 287-290, 2013.

16. Zhang WL, Zheng KY, Zhu KY, Zhan JY, Bi CW, Chen JP, Du CY, Zhao KJ, Lau DT, Dong TT and Tsim KW: Chemical and biological assessment of Angelica herbal decoction: Comparison of different preparations during historical applications. Phytomedicine 19: 1042-1048, 2012.

17. Kim BS, Seo H, Kim HJ, Bae SM, Son HN, Lee YJ, Ryu S, Park RW and Nam JO: Decursin from Angelica gigas Nakai inhibits B16F10 melanoma growth through induction of apoptosis. J Med Food 18: 1121-1127, 2015.

18. Cui R, He J, Wang B, Zhang F, Chen G, Yin S and Shen H: Suppressive effect of Astragalus membranaceus Bunge on chemical hepatocarcinogenesis in rats. Cancer Chemother Pharmacol 51: 75-80,2003.

19. Lv J, Zhao Z, Chen Y, Wang Q, Tao Y, Yang L, Fan TP and Liu C: The chinese herbal decoction danggui buxue tang inhibits angiogenesis in a rat model of liver fibrosis. Evid Based Complement Alternat Med 2012: 284963, 2012.

20. Shin JW, Son JY, Kang JK, Han SH, Cho CK and Son CG: Trichosanthes kirilowii tuber extract induces G2/M phase arrest via inhibition of tubulin polymerization in HepG2 cells. J Ethnopharmacol 115: 209-216, 2008.

21. Kongtun S, Jiratchariyakul W, Kummalue T, Tan-ariya P, Kunnachak S and Frahm AW: Cytotoxic properties of root extract and fruit juice of Trichosanthes cucumerina. Planta Med 75: 839-842, 2009.

22. Heo BG, Chon SU, Park YJ, Bae JH, Park SM, Park YS, Jang HG and Gorinstein S: Antiproliferative activity of Korean wild vegetables on different human tumor cell lines. Plant Foods Hum Nutr 64: 257-263, 2009.

23. Li LK, Kuang WJ, Huang YF, Xie HH, Chen G, Zhou QC, Wang BR and Wan LH: Anti-tumor effects of Astragalus on hepatocellular carcinoma in vivo. Indian J Pharmacol 44: 78-81, 2012.

24. Cho WC and Leung KN: In vitro and in vivo anti-tumor effects of Astragalus membranaceus. Cancer Lett 252: 43-54, 2007.

25. Cheng XD, Hou CH, Zhang XJ, Xie HY, Zhou WY, Yang L, Zhang SB and Qian RL: Effects of Huangqi (Hex) on inducing cell differentiation and cell death in K562 and HEL cells. Acta Biochim Biophys Sin (Shanghai) 36: 211-217, 2004.

26. Yin G, Tang D, Dai J, Liu M, Wu M, Sun YU, Yang Z, Hoffman RM, Li L, Zhang S and Guo X: Combination efficacy of astragalus membranaceus and curcuma wenyujin at different stages of tumor progression in an imageable orthotopic nude mouse model of metastatic human ovarian cancer expressing red fluorescent protein. Anticancer Res 35: 3193-3207, 2015.

27. Lee HJ, Lee HJ, Lee EO, Lee JH, Lee KS, Kim KH, Kim SH and Lü J: In vivo anti-cancer activity of Korean Angelica gigas and its major pyranocoumarin decursin. Am J Chin Med 37: 127-142, 2009.

28. Fang EF, Zhang CZ, Zhang L, Wong JH, Chan YS, Pan WL, Dan XL, Yin CM, Cho CH and Ng TB: Trichosanthin inhibits breast cancer cell proliferation in both cell lines and nude mice by promotion of apoptosis. PLoS One 7: e41592, 2012.

29. Li M, Li X and Li JC: Possible mechanisms of trichosanthin-induced apoptosis of tumor cells. Anat Rec (Hoboken) 293: 986-992, 2010.

30. Woo SM, Choi YK, Cho SG, Park S and Ko SG: A New Herbal Formula, KSG-002, suppresses breast cancer growth and metastasis by Targeting NF- $\kappa \mathrm{B}$-dependent TNF $\alpha$ production in macrophages. Evid Based Complement Alternat Med 2013: 728258, 2013.

31. Degterev A and Yuan J: Expansion and evolution of cell death programmes. Nat Rev Mol Cell Biol 9: 378-390, 2008.

32. Kerr JF, Wyllie AH and Currie AR: Apoptosis: A basic biological phenomenon with wide-ranging implications in tissue kinetics. Br J Cancer 26: 239-257, 1972.

33. Youle RJ and Strasser A: The BCL-2 protein family: Opposing activities that mediate cell death. Nat Rev Mol Cell Biol 9: 47-59, 2008.

34. Ola MS, Nawaz M and Ahsan $\mathrm{H}$ : Role of Bcl-2 family proteins and caspases in the regulation of apoptosis. Mol Cell Biochem 351: 41-58, 2011.

35. Mcllwain DR, Berger T and Mak TW: Caspase functions in cell death and disease. Cold Spring Harb Perspect Biol 5: a008656, 2013. 
36. Lavrik IN and Krammer PH: Regulation of CD95/Fas signaling at the DISC. Cell Death Differ 19: 36-41, 2012.

37. Vermeulen K, Van Bockstaele DR and Berneman ZN: The cell cycle: A review of regulation, deregulation and therapeutic targets in cancer. Cell Prolif 36: 131-149, 2003.

38. Song J, Li J, Qiao J, Jain S, Mark Evers B and Chung DH: PKD prevents $\mathrm{H} 2 \mathrm{O} 2$-induced apoptosis via NF-kappaB and p38 MAPK in RIE-1 cells. Biochem Biophys Res Commun 378 610-614, 2009

39. Song Y, Li X, Li Y, Li N, Shi X, Ding H, Zhang Y, Li X, Liu $G$ and Wang $Z$ : Non-esterified fatty acids activate the ROS-p38-p53/Nrf2 signaling pathway to induce bovine hepatocyte apoptosis in vitro. Apoptosis 19: 984-997, 2014

40. Circu ML and Aw TY: Reactive oxygen species, cellular redox systems, and apoptosis. Free Radic Biol Med 48: 749-762, 2010.

41. Trachootham D, Alexandre J and Huang P: Targeting cancer cells by ROS-mediated mechanisms: A radical therapeutic approach? Nat Rev Drug Discov 8: 579-591, 2009.

42. Chaithongyot S, Asgar A, Senawong G, Yowapuy A, Lattmann E, Sattayasai N and Senawong T: Anticancer effects of curcuma C20-dialdehyde against colon and cervical cancer cell lines. Asian Pac J Cancer Prev 16: 6513-6519, 2015.

43. Luo H, Wang F, Bai Y, Chen T and Zheng W: Selenium nanoparticles inhibit the growth of HeLa and MDA-MB-231 cells through induction of S phase arrest. Colloids Surf B Biointerfaces 94: 304-308, 2012

44. Song JM, Anandharaj A, Upadhyaya P, Kirtane AR, Kim JH, Hong KH, Panyam J and Kassie F: Honokiol suppresses lung tumorigenesis by targeting EGFR and its downstream effectors. Oncotarget 7: 57752-57769, 2016.
45. Wang S, Wu X, Tan M, Gong J, Tan W, Bian B, Chen M and Wang Y: Fighting fire with fire: Poisonous Chinese herbal medicine for cancer therapy. J Ethnopharmacol 140: 33-45, 2012.

46. Cheng HM, Li CC, Chen CY, Lo HY, Cheng WY, Lee CH, Yang SZ, Wu SL, Hsiang CY and Ho TY: Application of bioactivity database of Chinese herbal medicine on the therapeutic prediction, drug development, and safety evaluation. J Ethnopharmacol 132: 429-437, 2010

47. Choi YJ, Choi YK, Lee KM, Cho SG, Kang SY and Ko SG: SH003 induces apoptosis of DU145 prostate cancer cells by inhibiting ERK-involved pathway. BMC Complement Altern Med 16: 507, 2016.

48. Choi EK, Kim SM, Hong SW, Moon JH, Shin JS, Kim JH, Hwang IY, Jung SA, Lee DH, Lee EY, et al: SH003 selectively induces p73-dependent apoptosis in triple-negative breast cancer cells. Mol Med Rep 14: 3955-3960, 2016.

49. Woo SM, Kim AJ, Choi YK, Shin YC, Cho SG and Ko SG: Synergistic effect of $\mathrm{SHOO3}$ and doxorubicin in triple-negative breast cancer. Phytother Res 30: 1817-1823, 2016.

50. Hartwell LH and Weinert TA: Checkpoints: Controls that ensure the order of cell cycle events. Science 246: 629-634, 1989.

51. Liou GY and Storz P: Reactive oxygen species in cancer. Free Radic Res 44: 479-496, 2010

52. Storz P: Reactive oxygen species in tumor progression. Front Biosci 10: 1881-1896, 2005 